\title{
Európai és távol-keleti gyógynövények és kivonatok fémelemtartalom-vizsgálata
}

\author{
Süle Krisztina ${ }^{1,2}$ - Kurucz Dóra ${ }^{1,2}$ - Kajári Ágnes ${ }^{1,2}$ - May Zoltán dr. ${ }^{2}$ \\ ${ }^{1}$ Semmelweis Egyetem, Általános Orvostudományi Kar, Farmakognóziai Intézet, Budapest \\ ${ }^{2}$ MTA Természettudományi Kutatóközpont, Anyag- és Környezetkémiai Intézet, Budapest
}

\begin{abstract}
Bevezetés: A szervezetben lévő fémionegyensúly és a táplálkozás során felvett ásványi elemek szervezetre gyakorolt hatása, illetve a fémionterhelés szerepe alapvetően jelentős. Célkitüzés: Kevés kutatás szól arról, hogy a Távol-Keleten alkalmazott gyógynövények fémiontartalma mennyiben hasonló a hazai gyógynövényekéhez tisztasági szempontból és esszenciális fémtartalmukat tekintve, ezért a szerzők Európában és a távol-keleti gyógyászatban alkalmazott gyógynövények és kivonataik (alkoholos és szárított) mikro-, makroelem-tartalmának meghatározását tűzték ki célul. Módszer: Az európai gyógynövények közül a Calendula officinalis szirmának, az Achillea millefolium, Epilobium parviflorum herbájának, az Urtica dioica levelének és a Crataegus monogyna virágos ágvégének, a távol-keleti gyógynövények közül pedig a Cordyceps sinensis, a Ganoderma lucidum, a Ginkgo biloba levelének, a Panax ginseng gyökerének és a Curcuma longa kivonatainak fémiontartalmát határozták meg. Eredmények: A vizsgált drogok és kivonatok tisztasági szempontból megfelelnek az érvényben lévő előírásoknak, esszenciális elemtartalmuk és Ca:Mg arányuk hasonló. Következtetések: A kivonataik kedvező esszenciális fémionforrások és magnéziumtartalmuk is előnyös a Ca:Mg arány magnézium felé eltolódása miatt. Orv. Hetil., 2015, 156(31), 1261-1269.
\end{abstract}

Kulcsszavak: európai gyógynövény, kínai gyógynövény, kalcium, magnézium

\begin{abstract}
Investigation of metal element content of some European and Far Eastern herbs
Introduction: Metal elements and their excess intake have significant influence on general health. Aim: There is only little information how Far Eastern herbs resemble European's regarding their purity and essential metal element content. The aim of the authors was to determine metal elements in different Chinese and European herbs and extracts. Method: The studied European herbs included Calendula officinalis petals, Achillea millefolium, Epilobium parviflorum herba, Urtica dioica leaves, Crataegus monogyna flowers while Far Eastern herbs were Cordyceps sinensis, Ganoderma lucidum, Ginkgo biloba leaves, Panax ginseng and Curcuma longa roots. The analysis was performed using inductively coupled plasma optical emission spectroscopy. Results: There was no considerable difference in essential metal elements and the Ca:Mg concentration ratio between European and Far Eastern drugs and extracts. Conclusions: The extracts are preferential metal element sources and their magnesium content are also advantageous, because of a shift of the $\mathrm{Ca}: \mathrm{Mg}$ concentration ratio towards magnesium.
\end{abstract}

Keywords: European herb, Chinese herb, calcium, magnesium

Süle, K., Kurucz, D., Kajári, Á., May, Z. [Investigation of metal element content of some European and Far Eastern herbs]. Orv. Hetil., 2015, 156(31), 1261-1269.

(Beérkezett: 2015. április 15.; elfogadva: 2015. június 8.)

A közlemény a Fehér János Alapítvány pályázatán díjazott pályamunka.

\section{Rövidítések}

$\mathrm{Ag}=$ ezüst; $\mathrm{Al}=$ alumínium; $\mathrm{AP}-\mathrm{l}=$ aktivátor protein $\mathrm{l}$; $\mathrm{As}=$ arzén $; \mathrm{Au}=$ arany $\mathrm{B}=$ bór; $\mathrm{Ba}=$ bárium; $\mathrm{Bi}=$ bizmut; $\mathrm{Br}=$ bróm; $\mathrm{C}=$ szén $; \mathrm{Ca}=$ kalcium $; \mathrm{Cd}=$ kadmium $; \mathrm{Cl}=$ klór $;$
$\mathrm{Co}=$ kobalt $; \mathrm{Cr}=$ króm; $\mathrm{Cu}=$ réz $; \mathrm{CuZnSOD}=$ réz-cink-szuperoxid dizmutáz; EGF- $\alpha=$ epidermalis növekedési faktor- $\alpha$; $\mathrm{Fe}=$ vas; FGF- $\alpha=$ fibroblastnövekedési faktor $-\alpha$; Ge $=$ germánium; $\mathrm{H}=$ hidrogén; $\mathrm{Hg}$ = higany; $\mathrm{I}=$ jód; $\mathrm{I} k \mathrm{~B}$ kinázok = transz- 
kripciós faktor; IFN- $\alpha,-\gamma=$ interferon- $\alpha,-\gamma ;$ IL- $1,-6,-8=$ interleukin-1, $-6,-8 ;$ IP3 = inozitol-trifoszfát; $\mathrm{K}=$ kálium; $\mathrm{Li}=$ lítium; LT- $\alpha,-\beta=$ lymphotoxin- $\alpha,-\beta$; MAPK, MAPKKK $=$ mitogénaktivált proteinkinázok; $\mathrm{Mg}=$ magnézium; $\mathrm{Mn}=$ mangán; $\mathrm{MnSOD}=$ mangán-szuperoxid dizmutáz; $\mathrm{Mo}=$ molibdén; $\mathrm{N}=$ nitrogén; $\mathrm{Na}=$ nátrium; $\mathrm{NF}-\kappa \mathrm{B}=$ nukleáris faktor kappa-B; NF-AT = aktivált $\mathrm{T}$-sejt nukleáris faktor; $\mathrm{Ni}=$ nikkel; $\mathrm{O}=$ oxigén $; \mathrm{P}=$ foszfor $; \mathrm{Pb}=$ ólom; PDGF $=$ thrombocytaere detű növekedési faktor; $\mathrm{PKC}=$ proteinkináz $\mathrm{C}$; Raf-kináz $=$ protein szerin/treonin kináz; $\mathrm{Rb}=$ rubídium; $\mathrm{S}=$ kén; $\mathrm{Sb}=$ antimon; $\mathrm{Se}=$ szelén; $\mathrm{Si}=$ szilícium; $\mathrm{Sn}=$ ón; $\mathrm{Sr}=$ stroncium; TGF- $\beta=$ transzformáló növekedési faktor- $\beta ; \mathrm{Ti}=$ titán; TNF- $\alpha,-\beta=$ tumornekrózis-faktor $-\alpha,-\beta ; \mathrm{V}=$ vanádium; $\mathrm{Zn}=\operatorname{cink}$

A szervezetben lévő fémionegyensúly kutatása és a mindennapi táplálkozás során felvett ásványi elemek szervezetre gyakorolt hatásainak vizsgálata egyre nagyobb jelentőséget nyert az antioxidánskutatások mellett. A fémionok szervezetben lévő egyensúlyi koncentrációjának fenntartása a kiegyensúlyozott életvitelhez elengedhetetlen, mert DNS-szintig számos enzimfolyamatban vesznek részt kofaktorként és enzimaktivátorként. $\mathrm{Az}$ antioxidáns enzimrendszerben enzimalkotó komponensként vannak jelen például a cink és a réz a réz-cinkszuperoxid dizmutázban (CuZnSOD), a mangán a mangán-szuperoxid dizmutázban (MnSOD), a szelén a glutation-peroxidázban. A magnézium, mint antioxidáns, kalciumantagonistaként is részt vesz a redoxfolyamatok eliminálásában, a szabadgyök-termelés csökkentésében.

A humán szervezetben kimutatott elemek három biológiai osztályba sorolhatók: 1. Létfontosságú vagy eszszenciális elemek, amelyek közül makroelemek a szén (C), kalcium (Ca), hidrogén $(\mathrm{H})$, kálium $(\mathrm{K})$, klór $(\mathrm{Cl})$, magnézium $(\mathrm{Mg})$, nitrogén $(\mathrm{N})$, nátrium $(\mathrm{Na})$, oxigén $(\mathrm{O})$, foszfor $(\mathrm{P})$, kén $(\mathrm{S})$, és nyomelemek, mint a vas $(\mathrm{Fe})$, kobalt $(\mathrm{Co})$, réz $(\mathrm{Cu})$, jód $(\mathrm{I})$, mangán $(\mathrm{Mn})$, nikkel (Ni), molibdén (Mo), cink ( $\mathrm{Zn})$, króm (Cr) és szelén (Se). 2. Feltételesen létfontosságú elemek: arzén (As), bór $(\mathrm{B})$, bárium $(\mathrm{Ba})$, bróm $(\mathrm{Br})$, germánium $(\mathrm{Ge})$, rubídium $(\mathrm{Rb})$, szilícium $(\mathrm{Si})$, ón $(\mathrm{Sn})$, stroncium $(\mathrm{Sr})$, vanádium (V). 3. Nem létfontosságú elemek: ezüst (Ag), alumínium $(\mathrm{Al})$, bizmut $(\mathrm{Bi})$, kadmium $(\mathrm{Cd})$, ólom $(\mathrm{Pb})$, antimon $(\mathrm{Sb})$, arany $(\mathrm{Au})$ stb. Vitatott kérdés, hogy mely elemeket tekinthetjük toxikusnak. Megállapodás szerint egy elemet csupán minőségi megjelöléssel nem tekinthetünk mérgező hatásúnak. A toxikusságot csak az adott elem koncentrációjának megadásával jellemezhetjük. Kis mennyiségben és szúk határok között, részlegesen vagy feltételesen létfontosságú elemnek tekinthetők a közismerten veszélyes arzén és ólom is, illetve azt még nem bizonyították be, hogy semmilyen élettani hatással nem rendelkeznek.

A fémionokat táplálkozás során juttathatjuk be a szervezetbe, és ezek közül esszenciálisok azok, amelyek az élethez nélkülözhetetlen enzimatikus folyamatokban vesznek részt. Hiányuk súlyos egészségügyi problémákat, legrosszabb esetben halált is okozhatnak. Adott elemek mikro- vagy makroelem voltát az dönti el, hogy mekkora a szervezetben szükséges fiziológiai koncentrációjuk. A fémionok humán szervezetben lezajló folyamatainak vizsgálata egyre átfogóbb képet ad az egyes elemek élettani hatásairól. A nyomelemek részt vesznek a véralvadásban, vérképzésben, membrántranszport-folyamatokban, illetve enzimalkotóként bioszintetikus és lebontófolyamatokban.

A mindennapi táplálkozással bevitt ásványi anyagok megfelelő mértéke létfontosságú, mert az elemeket a szervezet nem képes előállítani. A táplálkozástudományban mára már néhány elem napi szükségleti és maximális beviteli szintjét meghatározták, de ez a lista és tartalma a mai napig is folyamatosan változik. Az elemek optimális szükséglete dózis szerint a hiány és a mérgező hatású mennyiség között helyezhető el, hiszen köztudott, hogy meghatározott tünetek alakulnak ki bizonyos elemek hiánya, illetve túladagolása következtében. A felboruló fémionegyensúly a jelátviteli utak folyamataiban is okoz változásokat. Az esszenciális, változó vegyértékú fémionok közül a $\mathrm{Cu}, \mathrm{Fe}, \mathrm{Mn}$, illetve a nem változó vegyértékű fémelemek közül pedig a S, Se, P, Mg, Ca, kulcsfontosságú szerepet töltenek be mind a biológiai oxidációban, mind az antioxidáns védekezőmechanizmusokban $[1,2,3]$. Hiányuk vagy túlzott feleslegük a sejtben lejátszódó jelátviteli folyamatokat jelentősen megváltoztatja $[4,5,6]$. Szerepük van továbbá az immunvédekezésben a nukleáris faktor kappa-B (NF- $\kappa \mathrm{B})$ transzkripciós faktor és az aktivátor protein 1 (AP-1) aktiválásán keresztül, illetve szabályozzák az IÆB-kinázok múködését. A fémionok redukciója az oxidatív stressz fokozódását válthatja ki, így befolyásolják az apoptózis és nekrózis folyamatát [1]. A magnézium például részt vesz a DNS-lánc kiépítésében és a fehérjeszintézisben a DNSpolimeráz-cink-enzim katalízisével. Továbbá részt vesz ioncsatornák és ionpumpák múködésének szabályozásában is. A Ca-ioncsatorna esetében a magnézium Ca-ioncsatorna-blokkoló. A Mg-ion a MgATP részét képezve közel az összes bioszintézisben jelen van, ahol energiafelhasználás történik molekuláris szinten. Ezenkívül a hemszintézis első lépésében, illetve a vitaminok anabolikus és katabolikus folyamataiban vesz részt $[2,4]$.

A kalcium szerepe a gyulladásos és immunfolyamatokban lényeges az NF- $\kappa$ B és AP-1 aktiválásán keresztül. Az intracelluláris kalciumkoncentráció növekedése és ezzel egy időben a magnéziumkoncentráció arányos csökkenése beindítja az inozitol-trifoszfát (IP3) termelődését, amelyek további Ca-ionokat mozgósítanak a kalszekvesztrinen és kalretikulinon keresztül. Az így mobilizálódó $\mathrm{Ca}^{2+}$-ionok hatására felszabadul a citoplazmában a proteinkináz C (PKC), amely további foszforilálással aktiválja a protein szerin/treonin kinázt (Raf-kináz), és közvetve az NF- $\kappa$ B transzkripciós faktort $[1,6,7]$.

Ez a jelátviteli kinázkaszkád a mitogénaktivált proteinkinázok (MAPK) aktiválódását eredményezi. A MAP ki- 
náz-kináz-kináz (MAPKKK) család tagjai foszforilálják a MAP-kináz-kinázokat, amelyek aktiválódnak és foszforilálják a MAP-kinázokat (MAPK), amely további transzkripciós faktorok (NF- $\kappa \mathrm{B} / \mathrm{I} \kappa \mathrm{B}, \mathrm{AP}-1$, aktivált T-sejt nukleáris faktor [NF-AT] stb.) múködését indítja be. Az aktiválódó $\mathrm{NF}-\kappa \mathrm{B}$ faktor bejut a sejtmagba, így beindítja az immun- és gyulladási folyamatokban lényeges gének átírását, amelynek során prooxidáns citokineket aktiválnak: interleukineket (IL-1, IL-6, IL-8), tumornekrózisfaktorokat (TNF- $\alpha,-\beta)$, amelyek további növekedési faktorokat (epidermalis növekedési faktor [EGF- $\alpha$, transzformáló növekedési faktor- $\beta$ [TGF- $\beta$ ], fibroblastnövekedési faktor- $\alpha[$ FGF- $\alpha]$, thrombocytaeredetü növekedési faktor [PDGF]), illetve interferonokat (IFN- $\alpha$, $-\gamma)$, lymphotoxinokat (LT- $\alpha$, LT- $\beta$ ) szabadítanak fel $[8$, $9,10,11,12]$.

A szervezetben lévő kalcium és magnézium intracelluláris szinten egymás antagonistáiként múködnek, ezért fontos figyelembe vennünk a szervezetünkbe jutó Ca és Mg megfelelő arányát. Néhány irodalom szerint magnéziumra van szükség a kalcium megfelelő felszívódása érdekében, ezért a nem megfelelő mennyiségü magnéziumbevitel is feltehetően oka lehet a szervezet kalciumhiányának. Egészséges emberek plazmájában a kalcium-magnézium 5:1 arányban van jelen, ezért azok a gyógynövények, amelyekben a Ca:Mg koncentrációarány ennél kisebb, kedvező terápiás hatást biztosíthatnak gyulladáscsökkentésben az emésztőrendszeri betegségek esetében. A vas szervezetben betöltött élettani szerepe ismert a legjobban (vérképzés, izmok, agy teljesítőképességének biztosítása). A protoporfirinnel stabil komplexet alkot (hem), illetve számos más hemoprotein prosztetikus csoportja (citokróm P450 enzimcsalád, flavin-monooxigenázok, peroxidázok), amelyeknek jelentős szerepe van a sejtben lejátszódó aerob folyamatokban. A vas megtalálható a sejt számos molekulájában, mint például a ferritinben, az oxigenázokban, a katalázban, a peroxidázokban, valamint a hidrolázok komponense is. A cink szerepe is mérvadó, hiszen körülbelül 300 igen fontos enzim alkotóeleme, ennek következtében a legfontosabb anyagcsere-folyamatokat befolyásolja, mint a szénhidrát-, fehérje-, lipid-, nukleinsav-anyagcsere [2].

Ismert, hogy a króm a vanádiummal a szénhidrátanyagcserében együttesen vesznek rész. Indukálják az inzulin termelését a krómszállító transzferrin transzportjának serkentésén keresztül [13]. Hiánya kóros glükóztoleranciát, túladagolása vese-, máj- és genetikai károsodást okoz. A kobalt a vasanyagcserében játszik fontos szerepet, illetve a $\mathrm{B}_{12}$-vitamin alkotójaként. Hiánya refrakter anémiát idéz elő, túladagolása pedig szívizom-károsodást okoz $[2,14]$.

$\mathrm{Az}$ egészséges szervezetben az esszenciális átmeneti fémionok koncentrációja szigorúan, míg a toxikus nehézfémek metabolizmusa gyengén szabályozott, ráadásul kiürülésük igen lassú. A nehézfémionok sejten belüli mozgása fehérjékhez kötött folyamat. A gyógynövények hatóanyag- és ásványielem-tartalmának szervezetbe történő bejuttatásához nem feltétlenül magát a növényt fogyasztjuk el, hanem különböző készítményeiket (teák, tinktúrák, kapszulák). Emiatt rendkívül fontos figyelmet fordítani a feldolgozás körülményeire is. A különböző körülmények között (víz, alkohol, hideg, meleg) történő kivonatkészítés során a kivonatok fémelem- és hatóanyag-tartalmai különbözőek lesznek.

A körömvirág (Calendula officinalis L.) szirmából, a kisvirágú füzikéből (Epilobium parviflorum Schreb.) és a csalán (Urtica dioica L.) leveléból készült kivonatok gyulladáscsökkentő, emellett immunerősítő hatásúak [15, 16, 17, 18]. A cickafark (Achillea millefolium L.) virágából készült tinktúrák is részben gyulladáscsökkentők, de emellett étvágyjavító, vírusellenes, görcsoldó és sebgyógyító hatásaik is vannak [19]. A galagonya (Crataegus monogyna) virágos ágvégéből készült tinktúrát az érrendszeri betegségekben használják kiegészítő terápiaként, mert vérnyomáscsökkentő, továbbá érelmeszesedés kockázatát csökkentő, így a coronariaerek vérellátásában és a szívizom anyagcseréjében is pozitív hatása van. Emellett szerepet játszik a rendszertelen szívritmus kiegyenlítésében, illetve a szívmúködés serkentésében [19, $20,21]$.

A gyógyszeres terápia mellett gyakran étrend-kiegészítőkkel próbálják pótolni a napi ásványielem- és vitaminbevitelt. Nagy jelentősége van a beviteli formák közül a hagyományos gyógyszerészetben alkalmazott tinktúráknak és kivonatoknak. Általánosan elmondható, hogy az alkohol alkalmasabb oldószer, mint a víz, mivel az alkohol oldja a növények szerves hatóanyagait és egyben konzervál is. A tinktúrák sokféle bioaktív komponenst (vitaminokat és polifenolokat, flavonoidokat) tartalmaznak a növényi drogokból, amelyek szervezetben történő metabolizmusára néhány, a biológiai oxidációban kulcsszerepet játszó fémelem ( $\mathrm{Fe}, \mathrm{Mn}, \mathrm{Cu})$ befolyással van. Ennek alapján feltehetően a tinktúrák fémelemtartalma is befolyásolja a tinktúrák antioxidánskapacitását, amely hozzájárul a gastrointestinalis betegségekben lejátszódó proinflammatorikus folyamatokat gátló hatásához.

A gyógynövényekkel való gyógyítás nagy szerepet játszik a hagyományos kínai orvoslásban. A nyugati országokban is egyre nagyobb teret hódít a kínai gyógynövényekkel történő gyógyítás, valamint egyes vegyületeket, növényi drogokat és kivonatokat gyógyszeripari alapanyagként is hasznosítanak. A cordyceps gomba (Cordyceps sinensis Berk.), más néven a kínai hernyógomba köhögés, bronchitis, vesebetegségek esetén alkalmazható. Emellett impotencia, anémia, szívritmuszavar, magas koleszterinszint, májbetegségek (hepatitis B), szédülés, gyengeség, fülzúgás ellen javallott. Ezenkívül immunerősítő és teljesítménynövelő hatását is leírták $[22,23]$. A pecsétviaszgombát (Ganoderma lucidum Fr. Karst.) máj- és mellkasi panaszok, illetve influenza, asztma esetén alkalmazzák a terápia kiegészítő részeként. Kedvezően hat a magas vérnyomásra és a magas koleszterinszintre, emellett a prosztatarákban antitumor-ellenes jótékony 
hatását is leírták. Alkalmazzák az alvászavarok helyreállítására, fáradékonyság ellen és a szellemi tevékenység fokozására. Alkalmas a kemoterápiás kezelés mellékhatásainak csökkentésére is [24, 25, 26, 27]. A páfrányfenyő (Ginkgo biloba L.) hatékony szorongáscsökkentő, emellett vérellátási zavarok, szédülés ellen is hatásos. Jótékony hatása van a visszértágulatra és az aranyérre, valamint a közepes depresszió és impotencia kezelésére is. Fokozza az anyagcserét, az agyi vérellátást, ezért öregkori demencia esetében és Alzheimer-kórban is használják. Javítja a perifériás keringést és a szem betegségeire is kedvezően hat $[28,29,30]$. A ginszeng (Panax ginseng L.) serkenti a gondolkodást, a koncentrációt, az emlékezést és a munkaképességet. Javítja az állóképességet és a fizikai teljesítőképességet, emellett kutatások bizonyítják, hogy kedvezően hat a depresszióra, a mellrákra, tüdőrákra és a bőrrákra is $[31,32]$. A kurkuma (Curcuma longa L.) jótékony hatással van az arthritisre, továbbá hasgörcs és hasmenés enyhítésére is alkalmazzák. Puffadás, étvágytalanság, májproblémák ellen kedvezően hat. Emellett gyulladáscsökkentő és Alzheimer-kórban is alkalmazható kiegészítő terápiaként, jótékony hatása miatt $[33,34,35]$.

Az emberek már ősidőktől fogva használtak gyógynövényeket a betegségek kezelésére, illetve manapság adjuváns terápiaként. A hagyományos nyugati gyógynövények és a kínai gyógynövények között csak részben van átfedés, ám a kínai elképzelések az emberi testről, illetve a növényekrôl és azok hatásairól különböznek a nyugati felfogástól. Gyakran hallunk a kínai élelmiszerbotrányokról, a nem megfelelő kínai élelmiszer-biztonságról vagy arról, hogy az importált gyógyszerkészítmények alapanyagaiban mérgező anyagokat fedeztek fel [36]. Ezért a nyugati országokban az egészségügyi hivatalok, más alternatív gyógymódokhoz hasonlóan, megpróbálják szabályozni a Kínából származó gyógyászati készítményeket, eljárásokat, így mára már számos kínai gyógynövény feketelistára került [37].

Ennek alapján célunk volt meghatározni néhány, Magyarország és Kína különböző területeirôl származó gyógynövény és az ezekből készített gyógyhatású kivonatok fémelemtartalmát.

\section{Módszer}

\section{Vizsgálati minták}

Vizsgálatainkhoz Európából származó gyógynövényeket, a cickafark (Achillea millefolium L.) herbáját, a csalán (Urtica dioica L.) levelét, a galagonya (Grataegus monogyna Jacq.) virágos ágvégét, a kisvirágú füzike (Epilobium parviflorum Schreb.) virágát, a körömvirág (Calendula officinalis L.) szirmát és ezeknek a drogok-

1. táblázat | Elemtartalom az európai gyógynövények drogjaiban (átlag \pm szórás, $\mu \mathrm{g} / \mathrm{g}, \mathrm{n}=3$ )

\begin{tabular}{|c|c|c|c|c|c|}
\hline & Cickafark herba & Csalánlevél & Galagonya virágos ágvég & Kisvirágú füzikevirág & Körömvirágszirom \\
\hline $\mathrm{Al}$ & $145,69 \pm 10,65$ & $476,8 \pm 6,3$ & $367,79 \pm 3,61$ & $98,62 \pm 4,66$ & $1558 \pm 3$ \\
\hline B & $91,24 \pm 10,31$ & $48,27 \pm 1,23$ & $95,46 \pm 0,79$ & $18,97 \pm 0,37$ & $141,85 \pm 19,67$ \\
\hline $\mathrm{Ba}$ & $6,381 \pm 0,22$ & $67,03 \pm 1,91$ & $51,89 \pm 0,88$ & $17,83 \pm 0,29$ & $6,88 \pm 0,29$ \\
\hline $\mathrm{Ca}$ & $7185 \pm 418$ & $53869 \pm 571$ & $6665 \pm 11$ & $10377 \pm 45$ & $5788 \pm 239$ \\
\hline $\mathrm{Co}$ & $<0,001$ & $<0,001$ & $1,18 \pm 0,006$ & $<0,001$ & $<0,001$ \\
\hline $\mathrm{Cr}$ & $4,65 \pm 0,37$ & $1,56 \pm 0,21$ & $1,51 \pm 0,03$ & $0,7 \pm 0,30$ & $6,17 \pm 0,34$ \\
\hline $\mathrm{Cu}$ & $6,51 \pm 0,73$ & $8,1 \pm 0,28$ & $1,28 \pm 0,17$ & $7,16 \pm 0,32$ & $8,26 \pm 0,22$ \\
\hline $\mathrm{Fe}$ & $138,4 \pm 10,1$ & $443,3 \pm 3,2$ & $880,2 \pm 3,7$ & $120,7 \pm 1,9$ & $1401 \pm 65$ \\
\hline $\mathrm{K}$ & $17536 \pm 895$ & $30282 \pm 42$ & $12047 \pm 32$ & $13883 \pm 96$ & $23539 \pm 136$ \\
\hline $\mathrm{Li}$ & $1,06 \pm 0,10$ & $15,04 \pm 2,36$ & $5,45 \pm 0,2$ & $<0,005$ & $0,69 \pm 0,052$ \\
\hline $\mathrm{Mg}$ & $2074 \pm 70$ & $5326 \pm 63$ & $1193 \pm 9$ & $2312 \pm 24$ & $2312 \pm 52$ \\
\hline $\mathrm{Mn}$ & $42,84 \pm 1,95$ & $52,73 \pm 0,21$ & $67,91 \pm 0,44$ & $88,02 \pm 2,08$ & $28,47 \pm 1,51$ \\
\hline $\mathrm{Na}$ & $223,6 \pm 52,4$ & $227 \pm 4,3$ & $178,71 \pm 1,03$ & $373,1 \pm 7,9$ & $4844 \pm 521$ \\
\hline $\mathrm{Ni}$ & $3,72 \pm 0,16$ & $<0,24$ & $2,62 \pm 0,065$ & $2,29 \pm 1,57$ & $3,56 \pm 0,15$ \\
\hline $\mathrm{P}$ & $2579 \pm 214$ & $6040 \pm 37$ & $2792 \pm 19$ & $2729 \pm 57$ & $1139 \pm 26$ \\
\hline $\mathrm{Pb}$ & $1,51 \pm 0,45$ & $<0,29$ & $1,15 \pm 0,19$ & $<0,29$ & $1,92 \pm, 13$ \\
\hline$S$ & $1594 \pm 63$ & $3933 \pm 62$ & * & $1713 \pm 48$ & $1347 \pm 64$ \\
\hline $\mathrm{Ti}$ & $3,946 \pm 0,155$ & $32,2 \pm 0,27$ & $<0,004$ & $2,26 \pm 0,49$ & $87,326 \pm 2,11$ \\
\hline $\mathrm{V}$ & $<0,149$ & $1,08 \pm 0,06$ & $0,65 \pm 0,08$ & $<0,149$ & $3,72 \pm 0,12$ \\
\hline $\mathrm{Zn}$ & $25,59 \pm 2,45$ & $95,7 \pm 6,36$ & $31,02 \pm 0,33$ & $26,45 \pm 0,36$ & $20,41 \pm 2,3$ \\
\hline
\end{tabular}

*Nincs adat. 
nak kereskedelmi forgalomban kapható, a Bioextra Kft. által forgalmazott alkoholos kivonatait vizsgáltuk. Az alkoholos-vizes oldatok alkoholtartalma $25 \mathrm{v} / \mathrm{v} \%$.

A távol-keleti gyógynövények közül Kína különbözó területeiről hazánkba került cordyceps gomba (Cordyceps sinensis Berk., Tibet), pecsétviaszgomba (Ganoderma lucidum Fr. Karst, Lian Yun Gang város), páfrányfenyő (Ginkgo biloba L., Jiang Shu), ginszeng (Panax ginseng L., Jin Lin tartomány), kurkuma (Curcuma longa L., Si Chuan tartomány) gyógynövénykivonatainak fémiontartalmát elemeztük.

\section{Vizsgálati módszerek}

Az elemtartalom meghatározásához analitikai pontossággal bemért, ismert mennyiségü $(0,5 \mathrm{~g})$ drogot és tinktúrát (2 g 25v/v\% alkoholos oldat, alkoholtartalom bepárlása után) roncsoltunk el $\mathrm{HNO}_{3}$ és $\mathrm{HCl}$ (3:1) és $\mathrm{H}_{2} \mathrm{O}_{2}$ elegyével $200{ }^{\circ} \mathrm{C}$-on. A feltárást követően a drogból készült mintákat kétszer desztillált vízzel 25 ml-re, a tinktúrákból készült mintákat 10 ml-re egészítettük ki, amelyből az elemek ( $\mathrm{Al}, \mathrm{As}, \mathrm{B}, \mathrm{Ba}, \mathrm{Ca}, \mathrm{Cd}, \mathrm{Cr}, \mathrm{Co}, \mathrm{Cu}$, $\mathrm{Fe}, \mathrm{Hg}, \mathrm{K}, \mathrm{Li}, \mathrm{Mg}, \mathrm{Mn}, \mathrm{Mo}, \mathrm{Na}, \mathrm{Ni}, \mathrm{P}, \mathrm{Pb}, \mathrm{S}, \mathrm{Ti}, \mathrm{V}, \mathrm{Zn}$ ) meghatározása Spectro Genesis ICP-OES készülékkel történt. A mintákban az As, Hg és Mo koncentrációja a kimutatási határ alá esett, ezért a táblázatokban nem szerepelnek.

\section{Eredmények}

Az 1. táblázat tartalmazza a vizsgált európai drogok ásványielem-tartalmát. A drogok elemtartalmaiban a legtöbb elem esetében szignifikáns különbségek láthatók. A körömvirág szirmának, a galagonya virágos ágvégének és a csalánlevélnek fémelemtartalmában egyes talajalkotó elemek nagyobb koncentrációt mutatnak ( $\mathrm{Cr}, \mathrm{Al}, \mathrm{Fe}$, Ti). Az eredményekből látható, hogy a B koncentrációja a kisvirágú füzike virágos ágvégében a legkisebb. A csalánlevélben vannak jelen a legnagyobb mennyiségben a következő elemek: $\mathrm{Li}, \mathrm{Ca}, \mathrm{Mg}, \mathrm{Zn}$. Látható, hogy rendkívül kiugró a Na mennyisége a körömvirág szirmából készült drogban.

A tinktúrák fémelemtartalmának eredményei (2. táblázat) alapján megállapítható, hogy a kivonatkészítéssel a drogban lévő esszenciális és toxikus elemek egyaránt kioldódnak, amelyek később az élő szervezetbe kerülhetnek. A cickafarkcseppek tartalmazzák legnagyobb menynyiségben a Fe-at, Li-ot, Ni-t, Pb-ot; a csaláncseppek az Al-ot, Ca-ot, Cr-ot, Mg-ot, S-t, Ti-t és Zn-et; a körömvirágcseppek a $\mathrm{B}$-t, $\mathrm{Cu}$-et, $\mathrm{K}$-ot, Na-ot és P-t, míg a galagonya- és a Kisvirágúfüzike-cseppek elemtartalmai a legkisebbek.

A 3. táblázat foglalja össze a távol-keleti étrend-kiegészítők alapanyagainak, gyógynövény-kivonatainak fémelemtartalmát. Nagyobb B-, Cr- és Ti-koncentrációk

2. táblázat | Elemtartalom az európai gyógynövények tinktúráiban (átlag \pm szórás, $\mu \mathrm{g} / \mathrm{ml}, \mathrm{n}=3$ )

\begin{tabular}{|c|c|c|c|c|c|}
\hline & Cickafarkcseppek & Csaláncseppek & Galagonyacseppek & Kisvirágúfüzike-cseppek & Körömvirágcseppek \\
\hline $\mathrm{Al}$ & $0,28 \pm 0,045$ & $6,01 \pm 0,1$ & $0,17 \pm 0,15$ & $0,046 \pm 0,01$ & $0,34 \pm 0,44$ \\
\hline $\mathrm{B}$ & $0,46 \pm 0,1$ & $0,38 \pm 0,02$ & $0,29 \pm 0,05$ & $0,18 \pm 0,03$ & $0,65 \pm 0,046$ \\
\hline $\mathrm{Ba}$ & $0,031 \pm 0,005$ & $0,034 \pm 0,003$ & $0,08 \pm 0,022$ & $0,076 \pm 0,004$ & $0,06 \pm 0,01$ \\
\hline $\mathrm{Ca}$ & $116,87 \pm 17,43$ & $348,29 \pm 1,51$ & $129,93 \pm 29,26$ & $140,59 \pm 15,93$ & $126,42 \pm 14,25$ \\
\hline $\mathrm{Co}$ & $0,013 \pm 0,001$ & $0,03 \pm 0,02$ & $0,032 \pm 0,018$ & $0,025 \pm 0,024$ & $0,026 \pm 0,011$ \\
\hline $\mathrm{Cr}$ & $0,2 \pm 0,18$ & $0,24 \pm 0,05$ & $0,069 \pm 0,012$ & $0,103 \pm 0,029$ & $0,063 \pm 0,002$ \\
\hline $\mathrm{Cu}$ & $0,31 \pm 0,04$ & $0,27 \pm 0,001$ & $0,19 \pm 0,044$ & $0,262 \pm 0,056$ & $0,54 \pm 0,038$ \\
\hline $\mathrm{Fe}$ & $1,3 \pm 0,49$ & $1,19 \pm 0,19$ & $0,44 \pm 0,15$ & $0,755 \pm 0,162$ & $1,11 \pm 0,39$ \\
\hline $\mathrm{K}$ & $1885 \pm 80$ & $1819 \pm 41$ & $1272 \pm 175$ & $1194 \pm 50$ & $1994 \pm 43$ \\
\hline $\mathrm{Li}$ & $0,41 \pm 0,036$ & $0,077 \pm 0,019$ & $0,065 \pm 0,015$ & $0,13 \pm 0,008$ & $0,078 \pm 0,033$ \\
\hline $\mathrm{Mg}$ & $237,06 \pm 18,4$ & $449,5 \pm 8,008$ & $328,95 \pm 37,54$ & $253,73 \pm 5,04$ & $300,37 \pm 7,36$ \\
\hline $\mathrm{Mn}$ & $0,81 \pm 0,013$ & $1,17 \pm 0,019$ & $1,08 \pm 0,11$ & $2,3 \pm 0,078$ & $0,53 \pm 0,044$ \\
\hline $\mathrm{Na}$ & $29,02 \pm 4,06$ & $17,59 \pm 0,33$ & $13,79 \pm 5,22$ & $46,13 \pm 1,52$ & $195,13 \pm 3,12$ \\
\hline $\mathrm{Ni}$ & $0,29 \pm 0,053$ & $0,15 \pm 0,065$ & $0,28 \pm 0,104$ & $0,26 \pm 0,08$ & $0,2 \pm 0,048$ \\
\hline $\mathrm{P}$ & $215,09 \pm 31,16$ & $14,87 \pm 0,57$ & $208,7 \pm 21,81$ & $295,6 \pm 7,9$ & $447,75 \pm 19,72$ \\
\hline $\mathrm{Pb}$ & $0,12 \pm 0,005$ & $0,078 \pm 0,006$ & $0,062 \pm 0,005$ & $0,033 \pm 0,002$ & $0,059 \pm 0,018$ \\
\hline$S$ & $108,57 \pm 14,89$ & $155,16 \pm 6,15$ & $140,18 \pm 23,27$ & $127,86 \pm 4,71$ & $126,39 \pm 4,17$ \\
\hline $\mathrm{Ti}$ & $0,021 \pm 0,008$ & $0,042 \pm 0,05$ & $0,013 \pm 0,004$ & $0,017 \pm 0,005$ & $0,022 \pm 0,016$ \\
\hline V & $<0,0171$ & $<0,0171$ & $<0,0171$ & $<0,0171$ & $<0,0171$ \\
\hline $\mathrm{Zn}$ & $1,53 \pm 0,064$ & $3,21 \pm 0,71$ & $1,7 \pm 0,59$ & $1,021 \pm 0,17$ & $2,18 \pm 0,032$ \\
\hline
\end{tabular}


3. táblázat | Elemtartalom a távol-keleti növények kivonataiban (átlag \pm Szórás, $\mu \mathrm{g} / \mathrm{g}, \mathrm{n}=3$ )

\begin{tabular}{|c|c|c|c|c|c|}
\hline & Ginszenggyökér & Kurkumagyökér & Cordyceps gomba & Ganoderma gomba & Ginkgolevél \\
\hline $\mathrm{Al}$ & $166,97 \pm 5,79$ & $27,71 \pm 4,11$ & $92,19 \pm 5,49$ & $151,35 \pm 16,87$ & $159,03 \pm 5,51$ \\
\hline B & $72,57 \pm 3,64$ & $61,84 \pm 2,24$ & $91,21 \pm 3,37$ & $120,03 \pm 32,34$ & $64,5 \pm 2,32$ \\
\hline $\mathrm{Ba}$ & $14,21 \pm 0,41$ & $0,24 \pm 0,02$ & $8,89 \pm 0,19$ & $4,08 \pm 0,07$ & $2,76 \pm 0,15$ \\
\hline $\mathrm{Ca}$ & $2816 \pm 87$ & $83,09 \pm 14,3$ & $8409 \pm 252$ & $790 \pm 41,5$ & $2691 \pm 43$ \\
\hline $\mathrm{Cd}$ & $0,08 \pm 0,01$ & $<0,03$ & $0,09 \pm 0,01$ & $0,26 \pm 0,01$ & $0,03 \pm 0,001$ \\
\hline $\mathrm{Co}$ & $0,16 \pm 0$ & $<0,017$ & $0,18 \pm 0,04$ & $0,06 \pm 0,01$ & $0,18 \pm 0,01$ \\
\hline $\mathrm{Cr}$ & $0,81 \pm 0,03$ & $0,42 \pm 0,03$ & $2,23 \pm 0,03$ & $7,83 \pm 0,85$ & $2,81 \pm 0,27$ \\
\hline $\mathrm{Cu}$ & $8,26 \pm 0,43$ & $0,29 \pm 0,03$ & $12,04 \pm 0,49$ & $14,1 \pm 0,76$ & $4,37 \pm 0,83$ \\
\hline $\mathrm{Fe}$ & $252,49 \pm 34,49$ & $4,74 \pm 0,85$ & $279,44 \pm 4,8$ & $183,24 \pm 6,62$ & $298,69 \pm 9,51$ \\
\hline $\mathrm{K}$ & $12843 \pm 739$ & $24,97 \pm 1,61$ & $7864 \pm 77$ & $1017 \pm 33$ & $11105 \pm 183$ \\
\hline $\mathrm{Li}$ & $0,15 \pm 0,02$ & $0,09 \pm 0,01$ & $0,12 \pm 0,01$ & $0,12 \pm 0$ & $0,4 \pm 0,08$ \\
\hline $\mathrm{Mg}$ & $1645 \pm 34$ & $58,87 \pm 1,28$ & $1488 \pm 15$ & $260,17 \pm 5,23$ & $1528 \pm 32$ \\
\hline $\mathrm{Mn}$ & $38,84 \pm 0,45$ & $0,19 \pm 0,03$ & $70,77 \pm 0,93$ & $14,1 \pm 1,12$ & $15,65 \pm 0,49$ \\
\hline $\mathrm{Na}$ & $175,99 \pm 10,05$ & $233,06 \pm 8,02$ & $350,08 \pm 12,76$ & $198,22 \pm 17,74$ & $503,7 \pm 42,2$ \\
\hline $\mathrm{Ni}$ & $0,67 \pm 0,01$ & $0,09 \pm 0,03$ & $5,51 \pm 0,09$ & $0,68 \pm 0,05$ & $3,33 \pm 0,06$ \\
\hline $\mathrm{P}$ & $3133 \pm 40$ & $45,67 \pm 1,15$ & $938 \pm 329$ & $1394 \pm 27$ & $1318 \pm 40$ \\
\hline$S$ & $1112 \pm 15$ & $98,72 \pm 1,21$ & $3561 \pm 78$ & $1086 \pm 31$ & $1039 \pm 25$ \\
\hline $\mathrm{Sr}$ & $20,73 \pm 0,31$ & $0,92 \pm 0,04$ & $17,59 \pm 0,45$ & $6,01 \pm 0,22$ & $13,49 \pm 0,05$ \\
\hline $\mathrm{Ti}$ & $6,23 \pm 0,68$ & $0,42 \pm 0,03$ & $3,22 \pm 0,34$ & $5,7 \pm 0,58$ & $4,56 \pm 0,4$ \\
\hline $\mathrm{V}$ & $0,3 \pm 0$ & $0,08 \pm 0,03$ & $0,3 \pm 0,03$ & $0,18 \pm 0,01$ & $0,27 \pm 0,05$ \\
\hline $\mathrm{Zn}$ & $22,25 \pm 0,44$ & $2,93 \pm 0,14$ & $44,67 \pm 0,7$ & $22,18 \pm 1,81$ & $23,54 \pm 1,21$ \\
\hline
\end{tabular}

láthatók a ginszenggyökér, ganoderma gomba, cordyceps gomba és Ginkgo biloba kivonataiban, valamint a Cr- és a B-tartalom a kurkumagyökér kivonatában is nagyobb a többi vizsgált mintához képest. A ginszeng gyökerében szignifikánsan nagyobb továbbá a Ba-, Ca-, $\mathrm{Mg-}, \mathrm{Cu}-, \mathrm{Fe}-, \mathrm{K}-$, P-tartalom a többi alapanyaghoz képest. A kurkumagyökér kivonatában jelentős Na-menynyiség van. A cordyceps gomba kivonatában a Ca-, Mn-, $\mathrm{Zn-}$, Ni- és S-tartalom jelentősen nagyobb, mint a többi növényi mintában, és figyelemre méltó a $\mathrm{Cu}^{-}, \mathrm{Fe}-, \mathrm{Mg}^{-}$, K- és Na-tartalom is. A ganoderma gombában a legnagyobb a $\mathrm{B}, \mathrm{Cd}, \mathrm{Cr}$ és $\mathrm{Cu}$ mennyisége, emellett nagy mennyiségben Fe-at, P-t és Zn-et tartalmaz. A ginkgo kivonata Fe-ban, Ca-ban, Mg-ban, K-ban, Na-ban, Pban, S-ben és Zn-ben gazdag. Ezek közül ennek van a legnagyobb Na- és Fe-tartalma, valamint az Al, B, Ti, Fe, $\mathrm{Ni}$ és Cr mennyisége is nagy. A ginszenggyökérnek, cordyceps gombának és ginkgolevélnek egyaránt jelentős a Ca- és Mg-tartalma. A ginszenggyökér, ganoderma gomba, cordyceps gomba és ginkgo kivonataiban található kis mennyiségű $\mathrm{Cd}$, amely a Ganoderma lucidumban a legmagasabb. A 3. táblázat alapján megállapítható, hogy a Cordyceps sinensis Ca- és P-tartalma messze meghaladja a vizsgált, Távol-Keletről származó növényekben mért kalcium- és foszfortartalmat, míg a Ganoderma lucidum esetében ez a mennyiség kisebb. A Ni és Cr menynyisége a cordyceps gomba kivonatban, a Cr mennyisége a Ganoderma lucidum kivonatában jelentős. Az esszenciális fémelemek közül a Cordyceps sinensis gomba kivonata jelentős mennyiségben $\mathrm{Zn}$-et, $\mathrm{Ca}$-ot, $\mathrm{Mg}$-ot és Feat tartalmaz, a Ganoderma lucidum pedig gazdag Cu-ben és Cr-ban.

\section{Megbeszélés}

A vizsgált drogok, étrend-kiegészítő alapanyagok, a kivonatok tisztasági szempontból megfelelnek a VIII. Magyar Gyógyszerkönyv és az Élelmiszerkönyv előírásainak, toxikusnak nevezett elemeket nem tartalmaznak a megengedett határértékek felett [38, 39].

Az európai növényi drogok közül néhányban az átlagos növényi koncentrációt meghaladó mennyiségben voltak jelen talajalkotó elemek, úgymint a $\mathrm{Cr}(>0,2$ $\mu \mathrm{g} / \mathrm{g}), \mathrm{Al}(>200 \mu \mathrm{g} / \mathrm{g}), \mathrm{Fe}(>300 \mu \mathrm{g} / \mathrm{g})$ és Ti (>2 $\mu \mathrm{g} / \mathrm{g})$, ami talajszennyezettségre, illetve a gyüjtés során nem megfelelő elókészítésre utalhat $[40,41]$. A B koncentrációja a kisvirágú füzike virágos ágvégének kivételével mindegyik vizsgált gyógynövényben a $40 \mu \mathrm{g} / \mathrm{g}$ (a növényekben átlagosan megtalálható) mennyiséghez képest nagyobb volt [42]. Ezeknek az elemeknek a kötelező vizsgálata azonban nem szükséges (alkoholos oldatokba való kioldódásuk csekély). A növényekben lévő átlagos Ca: $\mathrm{Mg}$ koncentrációarányhoz $(\mathrm{Ca}: \mathrm{Mg}$ 2,5:1,0) képest [43] a csalánlevélben, a kisvirágú füzike virágjá- 
ban és a galagonya virágos ágvégének drogjában jelentősen nagyobb volt ez az arány.

A tinktúrák gyorsan adszorbeálódnak a szervezet nyálkahártyáin keresztül, ezért nem feltétlenül szükséges a belekbe bekerülnie a tökéletes felszívódáshoz. Ez teszi lehetővé a tinktúrákban kis mennyiségben jelen lévő fémelemek és más bioaktív hatóanyagok viszonylagosan gyors és helyi hatáskifejtését. Általában a tinktúrák abszolút fémelemtartalma nem számottevően nagy, de a bennük jelen lévő kalcium, magnézium, cink, mangán és réz kulcsszerepet tölt be a szignáltranszdukciós utakban. Az alkoholt gyakran használják a gyógyszer-, parfüm- és az aromaiparban oldószerként. A tinktúrák a legősibb gyógyszerformának tekinthetők a gyógyszerészet történetében. A kivonatok fémelemtartalma függ a gyógynövény fémiontartalmától, és számos egyéb tényezőtől is, mint például a kivonatkészítés módjától (főzet, forrázat, áztatás), az oldószer minőségétől (víz, alkohol), illetve a környezeti körülményektől (idő, hőmérséklet) [44]. Az általunk vizsgált cseppekben megfigyelhető a tinktúrákra jellemző alacsony $\mathrm{Ca}: \mathrm{Mg}$ arány, ami nagyságrendileg 1:2-2:3 közötti érték, ami jobb magnéziumfelszívódást eredményezhet, így a gyulladásos folyamatokra is gátlóhatást fejthet ki $[45,46]$. Korábbi kutatásokban fémelemtartalmat vizsgáltak a gastrointestinalis betegségekben jelentkező gyulladásos folyamatokban kedvező hatású gyógynövények kivonataiban (Tinctura Ipecacuanhae normata, Tinctura Strychni, Tinctura Chinae), és ezekben az esetekben is megfigyelték, hogy a $\mathrm{Ca}: \mathrm{Mg}$ koncentrációarány a magnézium felé tolódott el, ami elősegíti a szervezetben a magnézium felszívódását, így a gyulladásos folyamatokban való kedvező hatását [21], amely hozzásegíthet a gastrointestinalis betegségekben lejátszódó proinflammatorikus folyamatokat gátló hatások enyhítéséhez.

A távol-keleti étrend-kiegészítők alapanyagaiként alkalmazott gyógynövények kivonatainak fémelemtartalmának vizsgálata során kiderült, hogy a Panax ginseng, a Ganoderma lucidum, a Cordyceps sinensis és a Ginkgo biloba kivonatokban mért B-, Cr- és Ti-koncentráció meghaladja a növényekben átlagosan jelen lévő $40 \mu \mathrm{g} / \mathrm{g}, 0,2$ $\mu \mathrm{g} / \mathrm{g}$ és 2,0 $\mu \mathrm{g} / \mathrm{g}$ koncentrációkat. Emellett a megemelkedett $\mathrm{Cr}$ - és B-tartalom is nagyobb a növényi átlagos koncentrációhoz képest a Curcuma longa kivonatában. A Cd koncentrációja is a detektálási határ felett van a Panax ginseng, Cordyceps sinensis, Ganoderma lucidum, Ginkgo biloba L. eseteiben, de nem haladja meg a növényekben előforduló átlagos Cd-koncentráció értékét $(\mathrm{Cd}>0,3 \mu \mathrm{g} / \mathrm{g})$ és a megengedett határértékeket [38, 39].

Kevés adat van arra vonatkozóan, hogy a Távol-Keleten olyan nagy sikerrel alkalmazott gyógynövények, illetve gyógyhatású készítmények hatóanyagai és összfémion-tartalma az európai populációra milyen terápiás hatással lehetnek. A vizsgált kínai növények többségében számos esszenciális fémelem $(\mathrm{Fe}, \mathrm{Zn}, \mathrm{Cu})$ koncentrációja magasabb. A ginszenggyökérnek, a cordyceps gombának és a ginkgolevélnek egyaránt jelentős a Ca- és $\mathrm{Mg}$-tartalma. A fenti növényekben lévő $\mathrm{Ca}: \mathrm{Mg}$ koncentrációarány is jelentősen nagyobb az európai gyógynövényekben találhatóakéhoz képest, ami a ginszeng gyökerében 1,7:1,0, a ginkgo kivonatában 1,8:1,0, míg a cordyceps gomba kivonatában a legnagyobb $(5,6: 1,0)$. A kurkumagyökér és a ganoderma gomba kivonatában ennek a két elemnek a mennyisége kisebb, de a kurkumagyökér Ca:Mg koncentrációaránya kedvezóbb, 1,4:1,0, míg a ganoderma gomba esetében a kalcium irányába van eltolódva $(3: 1)$.

Korábbi kutatásokban Budapesten az Eötvös Loránd Tudományegyetem botanikai kertjében termesztett Ginkgo biloba levelének és kivonatának (vizes és alkoholos) fémelemtartalmát vizsgálták hím- és nőivarú fajokban [6]. Vizsgálataik során a nőivarú etanolos oldatában jelentősen nagyobb mennyiségü alumíniumot találtak, míg a hímivarúban a vas koncentrációja volt nagyobb. A mangán és cink koncentrációja magasabb a hímivarú fajták vizes kivonataiban, mint az etanolosokban. A magnéziumtartalom jóval nagyobb volt a nóivarú levél vizes és alkoholos extraktumában, a hímivarú minták extraktumaihoz képest [46]. A magnéziumban gazdag nőivarú ginkgokivonat regenerálja az agyat, emellett megváltoztatja az idegrendszeri betegségekre kedvező hatású fémionok (Mg, Ca, K, Na, P, S és Zn) metabolikus koncentrációját [47].

Ezenkívül néhány fémion $(\mathrm{Al}, \mathrm{Cr}, \mathrm{B}, \mathrm{Fe}, \mathrm{Ni}, \mathrm{Ti})$ megemelkedett koncentrációban található a Kínából származó gyógynövényekben. A nehézfémek $(\mathrm{Cd}, \mathrm{Hg}$ és $\mathrm{Pb})$ sokkal nagyobb mértékben akkumulálódnak a gombafajokban, mint a zöld növényekben [46]. Míg a Ni és $\mathrm{Cr}$ együttes mennyisége a cordyceps gomba kivonatában, addig a Cr mennyisége a Ganoderma lucidum kivonatában haladja meg jelentős mértékben a növényekben található átlagos Ni- $(>4,0 \mu \mathrm{g} / \mathrm{g})$ és $\mathrm{Cr}-(>0,2 \mu \mathrm{g} / \mathrm{g})$ koncentrációt [42].

Köztudott, hogy a vadon élő, táplálékként fogyasztható gombák világszerte egyre gyakrabban fordulnak elő étrend-kiegészítőkben, mert az egészség és az immunrendszer erősítése szempontjából kedvező hatású fehérjéket, aminosavakat, pektineket, ribonukleázokat, alfaglükánokat, poliszacharidokat, antioxidánsokat és ásványi anyagokat tartalmaznak [48]. A cordyceps és ganoderma gombákat már ősidők óta alkalmazzák a hagyományos kínai és tibeti gyógyászatban, ezért különösen fontos a kutatásukra fektetett hangsúly a gyógyszer- és orvostudományban. A cordyceps gombafajtát elterjedten alkalmazzák a versenyző atléták, mert stimulálja az ATP-szintézist, javítja az állóképességet. Eddigi kutatások során számos kedvező hatása mellett hypoglykaemiás, antidepresszáns, máj- és vesevédő, koleszterinszint-normalizáló, tumorellenes, illetve hepatits B-ellenes hatását fedezték fel [49].

Az egészségre kedvező hatású szerves hatóanyag-tartalom mellett szükség van mind az esszenciális, mind pedig a toxikus fémelemtartalmuk vizsgálatára is, hiszen a 
zöld növények fiziológiai múködésétől jelentősen eltérnek. Összességében a toxikusnak nevezett fémionok a termékre megengedett határértékeket nem haladták meg, így mindennapi fogyasztásuk nem jelenthet különösebb veszélyt. A vizsgált gyógynövények és azok kivonatai hozzájárulhatnak a terápiát kiegészítő kedvező hatásokhoz, esszenciális elemtartalmuk és kedvező Ca:Mg arányuk miatt is. A növényekben lévő $\mathrm{Ca}: \mathrm{Mg}$ arány magas, míg a tinktúrákban ez az arány csökken és a Mg felé tolódik el. Ennek alapján a tinktúrák kedvező hatással lehetnek a magnézium felszívódásában, így a gyulladási folyamatokban is.

Anyagi támogatás: A cikk megírása és a kutatómunka anyagi támogatásban nem részesült.

Szerzői munkamegosztás: S. K.: Vizsgálat lefolytatása, hipotézisek kidolgozása, eredmények kiértékelése, kézirat megszövegezése. K. D.: Kísérletek előkészítése, kísérletek lefolytatása. K. Á.: Kísérletek előkészítése, kísérletek lefolytatása. M. Z.: Témavezetés, eredmények kiértékelése, tudományos szakmai tanácsok, annak érdekében, hogy a tudományos munka a megfelelő színvonalon megvalósulhasson. A szerzők a cikk végleges változatát elolvasták és jóváhagyták.

\section{Érdekeltségek: A szerzőknek nincsenek érdekeltségeik}

\section{Köszönetnyilvánítás}

Köszönet illeti a kutatás támogatásáért $D r$. Wang Fant, Dr. Chen Zhent és a Chen Patikát, valamint az Orient Kft.-t, akik a munkához szükséges alapanyagot biztosították. Köszönet illeti továbbá $D r$. Blázovics Anna professzor asszonyt szakmai tanácsaiért.

\section{Irodalom}

[1] Szentmibályi, K., Szilágyi, M., Balla, J., et al.: In vitro antioxidant activities of magnesium compounds used in food industry. Acta Alimentaria, 2014, 43(3), 419-425.

[2] Lakatos, B., Szentmibályi, K., Vinkler, P., et al.: Physiologic and pathologic role of iron in the human body. Iron deficiency anemia in newborn babies. [A vas fiziológiás és patológiás szerepe az emberi szervezet múköódésében. Az újszülöttek vashiányos anémiája.] Orv. Hetil., 2004, 145(36), 1853-1859. [Hungarian]

[3] Balla, J., Balla, Gy., Lakatos, B., et al.: Heme-iron in the human body. [A hemvas az emberi szervezetben.] Orv. Hetil., 2007, 148(36), 1699-1706. [Hungarian]

[4] Blázovics, A.: Redox homeostasis, bioactive agents and transduction therapy. Curr. Signal Transduction Ther., 2007, 2(3), 226239.

[5] Lakatos, B., Balla, J., Vinkler, P., et al.: The role of macro-elements in the human body. [Az esszenciális makrofémionok szerepe az emberi szervezet múködésében.] Orv. Hetil., 2006, 147(20), 925-930. [Hungarian]

[6] Stefanovits-Bányai, É., Szentmibályi, K., Hegedüs, A., et al.: Metal ion and antioxidant alterations in leaves between different sexes of Ginkgo biloba L. Life Sci., 2006, 78(10), 1049-1056.

[7] Gopalakrishna, R., Jaken, S.: Protein kinase C signaling and oxidative stress. Free Radic. Biol. Med., 2000, 28(9), 1349-1361.
[8] Erdei, A., Sármay, G., Prechl, J.: Immunology. [Immunológia.] Medicina Könyvkiadó, Budapest, 2012. [Hungarian]

[9] Lee, J. C., Laydon, J. T., McDonnell, P. C., et al.: A protein kinase involved in the regulation of inflammatory cytokine biosynthesis. Nature, 1994, 372(6508), 739-746.

[10] Bernardini, D., Nasulewic, A., Mazur, A., et al.: Magnesium and micerovascular endothelial cells: a role in inflammation and angiogenesis. Front. Biosci., 2005, 10, 1177-1182.

[11] Szentmihályi, K., May, Z., Kocsis, I., et al.: Magnesium supplementation and microelement homeostasis. Eur. Chem. Bull., $2012,1(8), 307-310$.

[12] Lawrence, T.: The nuclear factor NF- $\kappa \mathrm{B}$ pathway in inflammation. Cold Spring Harb. Perspect. Biol., 2009, 1(6), a001651.

[13] Vincent, J. B. (ed.): The Nutritional Biochemistry of Chromium(III). Elsevier, Amsterdam, 2011.

[14] Gibson, G. G., Skett, P.: Introduction to drug metabolism. Cengage Learning EMEA, Andover, 2001.

[15] Obertreis, B., Giller, K., Teucher, T., et al.: Anti-inflammatory effect of Urtica dioica folia extract in comparison to caffeic malic acid. Arzneimittel-Forschung, 1996, 46(1), 52-56.

[16] Martin, R. J., Deo, B.: Effect of plant population on calendula (Calendula officinalis L.) flower production. New Z. J. Crop Horticult. Sci., 2000, 28(1), 37-44.

[17] Kiss, A. K., Bazylko, A., Filipek, A., et al.: Oenothein B's contribution to the anti-inflammatory and antioxidant activity of Epilobium sp. Phytomedicine, 2011, 18(7), 557-560.

[18] Benedek, B., Kopp, B., Melzig, M. F., et al.: Achillea millefolium L. s.l. - Is the anti-inflammatory activity mediated by protease inhibition? J. Ethnopharmacol., 2007, 113(2), 312-317.

[19] Zhang, Z., Chang, Q., Zhu, M., et al.: Characterization of antioxidants present in hawthorn fruits. J. Nutr. Biochem., 2001, $12(3), 144-152$.

[20] Von Eiff, M., Brunner, H., Haegeli, A., et al.: Hawthorn/passion flower extract and improvement in physical exercise capacity of patients with dyspnoea Class II of the NYHA functional classification. Acta Ther., 1994, 20, 47-66.

[21] Weihmayr, T., Ernst, E.: Therapeutic effectiveness of Crataegus. Fortschr. Med., 1996, 114(1-2), 27-29.

[22] Liu, Y. K., Shen, W.: Inhibitive effect of Cordyceps sinensis on experimental hepatic fibrosis and its possible mechanism. World J. Gastroenterol., 2003, 9(3), 529-533.

[23] Yamaguchi, Y., Kagota, S., Nakamura, K., et al.: Inhibitory effects of water extracts from fruiting bodies of cultured Cordyceps sinensis on raised serum lipid peroxide levels and aortic cholesterol deposition in atherosclerotic mice. Phytother. Res., 2000, $14(8), 650-652$.

[24] Kabir, Y., Kimura, S., Tamura, T., et al.: Dietary effect of Ganoderma lucidum mushroom on blood pressure and lipid levels in spontaneously hypertensive rats (SHR). J. Nutr. Sci. Vitaminol. (Tokyo), 1988, 34(4), 433-438

[25] Maruyama, H., Yamazaki, K., Murofushi, S., et al.: Antitumor activity of Sarcodon aspratus (BERK.) S. ITO and Ganoderma lucidum (FR.) KARST. J. Pharmacobiodyn., 1989, 12(2), 118123.

[26] Hikino, H., Konno, C., Mirin, Ү., et al.: Isolation and hypoglycemic activity of ganoderans A and B, glycans of Ganoderma lucidum fruit bodies. Planta Med., 1985, 51(4), 339-340.

[27] Sliva, D., Labarrere, C., Slivova, V., et al.: Ganoderma lucidum suppresses motility of highly invasive breast and prostate cancer cells. Biochem. Biophys. Res. Commun., 2002, 298(4), 603612.

[28] Zhang, J. J., Zhong, X. M.: Natural drug in senile dementia treatment: research progress. J. Liaoning Univ. Tradit. Chinese Med., 2009.

[29] Le Bars, P. L., Katz, M. M., Berman, N., et al.: A placebo-controlled, double-blind, randomized trial of an extract of Ginkgo biloba for dementia. JAMA, 1997, 278(16), 1327-1332. 
[30] Jung, F., Mrowietz, C., Kiesewetter, H., et al.: Effect of Ginkgo biloba on fluidity of blood and peripheral microcirculation in volunteers. Arzneimittel-Forschung, 1990, 40(5), 589-593.

[31] Yun, T. K., Lee, Y. S., Lee, Y. H., et al.: Anticarcinogenic effect of Panax ginseng C.A. Meyer and identification of active compounds. J. Korean Med. Sci., 2001, 16(Suppl.), S6-S18.

[32] Jung, C. H., Seog, H. M., Choi, I. W., et al.: Effects of wild ginseng (Panax ginseng C.A. Meyer) leaves on lipid peroxidation levels and antioxidant enzyme activities in streptozotocin diabetic rats. J. Ethnopharmacol., 2005, 98(3), 245-250.

[33] Kawamori, T., Lubet, R., Steele, V. E., et al.: Chemopreventive effect of curcumin, a naturally occurring anti-inflammatory agent, during the promotion/progression stages of colon cancer. Cancer Res., 1999, 59(3), 597-601.

[34] Conney, H. A., Lysz, T., Ferraro T., et al.: Inhibitory effect of curcumin and some related dietary compounds on tumor promotion and arachidonic acid metabolism in mouse skin. Adv. Enzyme Regul., 1991, 31, 385-396.

[35] Cole, M. G., Teter, B., Frautschy, S. A.: Neuroprotective effects of curcumin. Adv. Exp. Med. Biol., 2007, 595, 197-212.

[36] Adams, C.: Chinese herbs tainted with pesticides and heavy metals - what to do. Heal Naturally, 2015. http://www.realnatural. org/chinese-herbs-tainted-with-pesticides-and-heavy-metalswhat-to-do/

[37] Blázovics, A., Szentmibályi, K., Lugasi, A., et al.: In vitro analysis of the properties of Beiqishen tea. Nutrition, 2003, 19(10), 869875.

[38] Hungarica Pharmacopoeia VIII. [Magyar Gyógyszerkönyv VIII.] Medicina Könyvkiadó, Budapest, 2004. [Hungarian]

[39] Codex Alimentarius Hungaricus. [Magyar élelmiszerkönyv.] Élelmiszer szabályozási információk 10. Vidékfejlesztési Minisztérium, Budapest, 2013. [Hungarian]

[40] Szentmibályi, K., Then, M.: Examination of microelements in medicinal plants of the Carpathian Basin. Acta Alimentaria, $2007,36(2), 231-236$.
[41] Szentmibályi, K., Hajdú, M., Then, M., et al.: Inorganic biochem istry of medicinal plants. Med. Aromat. Plant Sci. Biotechnol., 2008, 2, 57-62.

[42] Kabata-Pendias, A., Pendias, H.: Trace elements in soils and plants. CRC Press, Inc., Boca Raton, 1984.

[43] Szentmibályi, K., Kéry, Á., Lakatos, B., et al.: New results for phytotherapeutic evaluations of common chicory (Cichorium intybus L.). [Újabb kutatási eredmények a katángkóró (Cichorium intybus L.) fitoterápiás értékeléséhez.] Fitoterápia, 1996, 2(4), 125131. [Hungarian]

[44] Szentmibályi, K., Hajdu, M., Then, M.: Trace elements in medicinal plants and extracts and their potential beneficial and toxic effects. In: Szilágyi, M., Szentmihályi, K. (eds.): Trace elements in the food chain. Institute of Materials and Environmental Chemistry of the HAS, Budapest, 2006.

[45] Newnham, R. E.: The role of boron in human nutrition. J. Applied Nutrition, 1994, 46, 81-85.

[46] Konuk, M., Afyon, A., Yağız, D., et al.: Minor element and heavy metal contents of wild growing and edible mushrooms from Western Black Sea Region of Turkey. Fresenius Environmental Bulletin, 2007, 16(11a), 1359-1362.

[47] Yasui, M., Kibira, T., Ota, K.: Calcium, magnesium and aluminium concentrations in Parkinson's disease. Neurotoxicology, $1992,13(3), 593-600$.

[48] Ikekawa, T.: Beneficial effects of edible and medicinal mushrooms on health care. Int. J. Med. Mushrooms, 2001, 3, 291298.

[49] $L i, X . T ., L i, H . C ., L i, C$. B., et al.: Protective effects on mitochondria and anti-aging activity of polysaccharides from cultivated fruiting bodies of Cordyceps militaris. Am. J. Chin. Med., $2010,38(6), 1093-1106$.

(May Zoltán dr., Budapest, Magyar tudósok körútja 2., 1117 ; 1519 Budapest, Pf. 286 e-mail: may.zoltan@ttk.mta.hu)

\section{ÁLLÁS}

A sárvári Szent László Kórház főigazgatója pályázatot hirdet szakorvos/szakorvosjelölti állásokra.

Jelentkezés írásban, szakmai önéletrajzzal 2015. július 31-ig az alábbi címen:

Szent László Kórház, 9600 Sárvár, Rákóczi u. 30.

A pályázati felhívás 2015. július 13-tól megtekinthető a www.kozigallas.gov.hu oldalon. 